\title{
Comparision of different application methods to biological control Hypothenemus hampei
}

\author{
Raquel Moraes Costa Pereira ${ }^{1}$, José Eduardo Marcondes de Almeida ${ }^{2}$, Antonio Batista Filho ${ }^{1}$ (iD
}

${ }^{1}$ Instituto Biológico de São Paulo/IB, São Paulo, SP, Brasil

${ }^{2}$ Instituto Biológico de São Paulo/IB, Campinas, SP, Brasil

Contact authors: gestao.ma@hotmail.com; jose.marcondes@sp.gov.br; batistafilhoantonio@gmail.com

Received in December 21, 2020 and approved in June 2, 2021

\section{ABSTRACT}

There are several studies that deal with the problem of infestation by Hypothenemus hampei in Coffeea arabica. However, the ways of applying products based on entomopathogenic fungi are the same as those used for chemicals. The objective of the research was to comparison different methods of application of Beauveria bassiana against $H$. hampei. The experiments were developed in laboratory, with blastospores and B. bassiana airborne conidia powders were carried out. Application methods based on immersion, Potter Spray Tower and walking on treated surface. Were three experiments were carried out for each method. Bioassays'design comprised seven treatments (including the control), with five repetitions (each) and 25 beetles per repetition. Suspensions were standardized at $2.4 \times 10^{9}, 1 \times 10^{9}, 5 \times 10^{8}, 1 \times 10^{8}, 5 \times 10^{7}$ and $1 \times 10^{7}$ conidia. $\mathrm{mL}^{-1}$. Conidia powder presented initial concentration of $1.14 \times 10^{10}$ and it was standardized at $1.14 \times 10^{9} ; 5.7 \times 10^{9} ; 1.14 \times 10^{8} ; 5.7 \times 10^{7} ; 1.14 \times 10^{7}$ and $5.7 \times 10^{6}$ conidia. . $^{-1}$. A simultaneous test was also carried out based to the three application methods; treatment comprised conidia powder concentration of $1 \times 10^{8}$ and the control. Data were subjected to analysis of variance, which was followed by Tukey test $(\mathrm{P}<0.05)$ and, $\mathrm{CL}_{50}$, in the SPSS 12.1 software. The mortality better rates of $H$. hampei exposed to B. bassiana IBCB66 were $1 \times 10^{8}$ (immersion), $1 \times 10^{9}$ (Potter Spray Tower) and $1 \times 10^{8}$ (walking), where as mean $\mathrm{LC}_{50}$ were $6.1 \times 10^{8}, 4.1 \times 10^{8}, 2.4 \times 10^{8} \mathrm{conidia}$. $\mathrm{mL}^{-1}$ for each method, respectively. The highest mortality rate was recorded in the walking tests on the conidian powder at a concentration of $1 \times 10^{8}$ conidia. ${ }^{-1}$ for the three repetitions of the method and also in the simultaneous test.

Key words: Blastospores; Conidian powder; Mortality; Suspensions.

\section{INTRODUCTION}

Hypothenemus hampei (Coleoptera: Curculionidae) is a pest capable of significantly affecting coffee crops worldwide, Infante, Pérez and Veja (2012). It is not easily controlled, since it is monophagous, cryptic, multivoltine and capable of attacking coffee fruits at any fruit development stage, consequently, it can lead to significant financial losses. In addition, this borer beetle does colonize coffee fruits in all phases of grow and the injury caused by it, enables fruit contamination with other organisms which also leads to damage, Mota et al. (2017); Parra and Reis (2013); Souza et al. (2013). Also, the action of borer beetles generates significant losses caused by their metabolites and off spring inside the fruit, among other microorganisms. Consequently coffee grains weight for sale decreases, as well as the final quality of the beverage, Jaramillo, Borgemeister and Baker (2006); Bratodjojo et al. (2020).

In addition, this pest is overall controlled by the application of synthetic pesticides capable of causing presents resistance cases. Furthermore, the organochlorine endosulfan was banned by the National Health Surveillance Agency (ANVISA) in 2013 due to its teratogenic and cumulative effects on the environment. With that increased concerns about $H$. hampei proliferation in coffees crops have increased, Jaramillo et al. (2011); Mota et al.(2017); Neves and Hirose (2005).

This scenario has leads coffee producers sought alternatives based on biological control without negatives effects to the enviromental, as an eco-friendlytactics and sustainable tactic. Also, has raised concerns among producers, who have sought alternatives based on biological control to decrease problems with crop resistance to insecticides and the emergence, Bratodjojo et al. (2020); Parra et al.(2002).

The advantages of using biological control based on entomopathogenic microorganisms comprise reduced use of chemical insecticides and, consequently, reduced production costs, non-environmental pollution and lack of damage to nontarget organisms and humans Alves, Neves and Faria (2010); Brasil (2017); Mascarin and Pauli (2010); Parra and Reis (2013).

Entomopathogen B.bassiana is cosmopolitan since it presents broad-spectrum action against several pests.It happens naturally in the environment and causes epizootic in $H$. hampei it is also used to control coleoborers, Almeida et al.(2009); Alves (1992); Alves(1998); Parra and Reis (2013); Santoro et al. (2007).

It is well-known that entomopathogens such as $B$. bassiana mostly act by getting in contact with insects; therefore, it is essential evaluating the application methods available in the market.

The application methodologies for entomopathogenic fungi are still the same used in chemical control, Guimarães, Correia, and Ferreira (2004). Most of the experiments carried out in the laboratory are carried out by spraying, immersion or trapping methods. Thus, there is prevalence in the use of aerial conidia of entomopathogenic fungi but, in general, they are applied by means of suspension, sprinkling and traps. 
Batista Filho, Alves and Muniz (1992), have conducted a study focused on treating coffee fruits with $B$. bassiana (at concentration of $3 \times 10^{6}$ conidia. $\mathrm{mL}^{-1}$ ) and recorded $80 \%$ insectpest mortality rate. According to Mota et al. (2017), fungal species $B$. bassiana used in synthetic tissues surface treatment, at concentration of $5.44 \times 10^{8} . \mathrm{cm}^{-2}$, recorded $88.5 \% \mathrm{H}$. hampei mortality rate after five seconds of exposure to it. Immersion based studies conducted with different $B$. bassiana isolates against $H$. hampei recorded up to $100 \%$ insect mortality rate, Gerónimo-Torres et al. (2016); Posada-Flórez (2008).

There are several products with formulations based on entomopathogenic fungi, whose indications for dilution, whether in oil or inert. However, there are few studies with methodology for applying powder aerial conidia directly to the insect's body, without any type of vehicle. In addition, since the equipment and application methodologies are the same as in conventional agriculture, there may be a decrease in the efficiency of the entomopathogen due to possible negative impacts on the structures of conidia caused, in general, by the poor regulation or handling of traditional equipment in agriculture, Rodrigues, Almeida and Duarte (2019).

Several other experiments have already been carried out to identify higher $B$. bassiana using efficiency levels associated with $H$. hampei control. However, the need of carrying out laboratory experiments to help improving methodologies focused on entomopathogenic microorganism applications remains. Therefore, the objective of the research was to comparison different methods of application of $B$. bassiana against $H$. hampei.

\section{MATERIAL AND METHODS}

1) Insect: The $H$. hampei insects were initially brought from the field and then reared under laboratory conditions, with a view to obtaining insects in sufficient quantity and at an approximate age to carry out the experiments. After cleaning and drying, the material was left to dry in the shade for 48 hours, the fruits were transferred and placed in tubular PVC cages $(0.25 \mathrm{~m}$ high and $0.10 \mathrm{~m}$ in diameter), with PVC cover. One end was defined as the bottom of the cage it had a screen (opening of $0.025 \mathrm{~m}$ and an area of approximately $0.15 \times 0.15 \mathrm{~m}$ ) attached to it with an elastic band to facilitate the handling and removal of insects for the bioassays. The ambient temperature was maintained $25 \pm 3{ }^{\circ} \mathrm{C}$ and the $\mathrm{RH}$ was \pm 60 . Adult females, approximately 35 days old, were used.

2) Fungus: The Beauveria bassiana IBCB66 used in the experiments had origin in "Oldemar Cardim Abreu" Entomopathogenic Fungi Collection, Biological Institute in Campinas, SP. This is strains was previously selected to $H$. hampei, Almeida et al. (2009). Based on the current legislation and on data from the Agrofit database, IBCB66 it is registered as phytosanitary product to be used in organic agriculture, Brasil
(2020). IBCB66 strain reproduction for bioassays was carried out based on Alves (1998), on technical report 03 by Laurentino and Costa (2004); Hirose and Neves (2005) and Leite et al. (2003).

3) Bioassays: three bioassays were carried out for each of the three methods: immersion, suspension in Potter Tower and walking-on-conidia powder, and a single bioassay was carried out simultaneously with the three methods, totaled 10 experiments. Each experiment comprised 7 treatments, including the control, and 5 replicates comprising 25 insects divided into 5 Petri dishes with 5 insects (each). Fungal suspensions with only distilled water, concentrations were standardized at $2.4 \times 10^{9}, 1 \times 10^{9}, 5 \times 10^{8}, 1 \times 10^{8}, 5 \times 10^{7}$ and $1 \times 10^{7}$ conidia. $\mathrm{mL}^{-1}$. Airborne conidia powder presented initial concentration of $1.14 \times 10^{10}$ conidia.g $^{-1}$, where as the other concentrations were standardized at $1.14 \times 10^{9}, 5.7 \times 10^{9}$, $1.14 \times 10^{8}, 5.7 \times 10^{7}, 1.14 \times 10^{7}$ and $5.7 \times 10^{6}$ conidia. $^{-1}$. In the simultaneous experiment, for the three methods, the design was a treatment with a concentration of $1 \times \times 10^{8}$ and a control, with five repetitions with the same amount of insects from the other experiments. In total, 1.725 coffee borers, adults females and around 35 days old were used in the experiment. Specimens were removed from the breeding process, either the day before or at the experimental day itself, by means of selection performed on paper towel they were handled with soft brush. Twenty-five (25) H. hampei individuals were placed in a single Petri dish for each treatment. Natural diet comprising chips of freshly-harvested coffee fruits of approximately 0.005 $\mathrm{m}$ was introduced 24 hours after the experiments.

4) Evaluations: Experiments were evaluated on a daily basis, for up to 10 days, in order to observe insects' overall conditions and mortality rate. The evaluations were under Stemi DV4 Zeizz ${ }^{\circledR}$ stereomicroscope equipped with double light and increased visualization ranging from 12 to 16 times depending on the need of clarity. Insects were handled with soft brush which was sanitized with $70 \%$ alcohol, every time they were used. Adult coffee borer mortality was evaluated at different concentrations and modes of application of the $B$. bassiana fungus conidia or blastospores, in order to determine the best concentration to be used in the experiment to evaluate the application methods in the same test. The experimental design was completely randomized for the first three experiments with seven treatments and five repetitions each. In the experiment of comparing application methods, the same design was used, but with four treatments and five repetitions.

5) Statistical analysis was applied to data in order to assess mortality rates the average number of deaths per treatment recording only of the insect mortality and the average number of deaths per treatment and for each application method. It was done through analysis of variance (ANOVA); means were compared through Tukey test $(\mathrm{P}<0.05)$, and through $\mathrm{LC}_{50}$ (ProbitX2 $=17,56$, sig. 0,01) in the SPSS software version 12.1 . 


\section{RESULTS}

In analysis of the teststhe observation of eggs during insects' mortality evaluation corroborates data available in the literature, according to which, adult female $H$. hampei insects emerge from fruits after copulation (Figure 1).

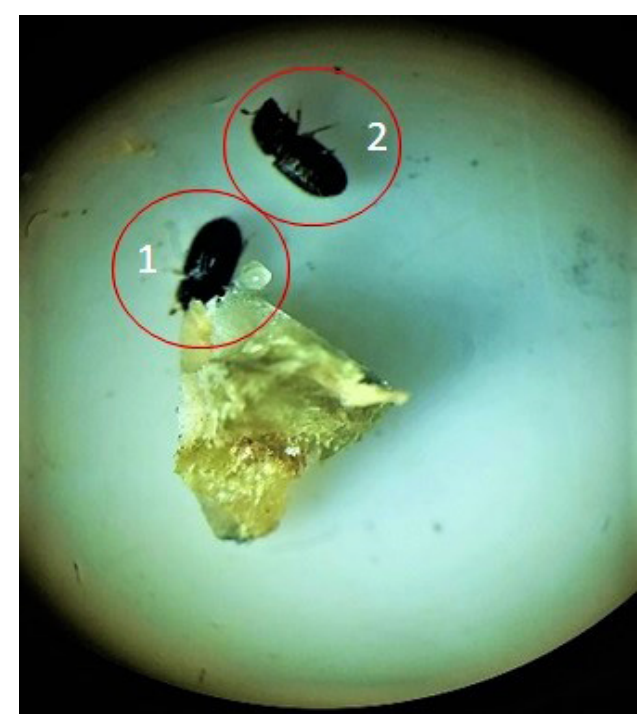

Figure 1: Daily mortality analysis, Hypothenemus hampei 48 hours after fungal suspension spraying with Potter Spray Tower; 1: Live $H$. hampei and egg laid on diet grains; 2: Dead $H$. hampei. Source: By author.

Mean mortality recorded in the immersion-based experiments (blastospore suspension of $B$. bassiana) showed a higher number of deaths in the $2.4 \times 10^{9}$ concentration for test 1 , which presented an average number of dead individuals equal to 4.60. The most efficient concentration used in test 2, for this method, was $1 \times 10^{8}$, with an average number of deaths equal to 4.80 . The most efficient concentration used in test 3 was $5 \times 10^{7}$ average number of deaths equal to 4.60 (Figure 2).
Mean $\mathrm{LC}_{50}$ in the immersion experiment was $6.1 \times 10^{8}$ conidia. $\mathrm{mL}^{-1}$ and it showed that the most efficient concentration ranged from $1 \times 10^{8}$ conidia. $\mathrm{mL}^{-1}$ to $1 \times 10^{9}$ conidia. $\mathrm{mL}^{-1}$.

In the experiments carried out by the spraying method in Potter's Tower, there was no statistically significant difference between the concentrations. However, the concentration $1 \times 10^{9}$ conidia. $\mathrm{mL}^{-1}$ was the most efficient with an average mortality of 4.60 in the test 1 . On the other hand, the concentration $5 \times 10^{7}$ conidia. $\mathrm{mL}^{-1}$ was the most efficient concentration used in test 2 , which recorded mean number of dead individuals equal to 4.20. Mean mortality rate in test 3 was lower than that observed for the first tests. The highest mortality rate observed in this test was recorded at concentration of $5 \times 10^{7}$ conidia. $\mathrm{mL}^{-1}$ (Figure 3 ).

Mean $\mathrm{LC}_{50}$ in experiment by application with Potter Spray Tower was $4.1 \times 10^{8}$ conidia. $\mathrm{mL}^{-1}$, which was remarkably close to the concentration of $5 \times 10^{8}$ conidia. $\mathrm{mL}^{-1}$ used in one of the treatments. Based on the comparison among all 3 tests, the highest mortality rates were recorded for test 1 .

With respect tothe walking tests, the concentration of $1 \times 10^{8}$ conidia. $\mathrm{mL}^{-1}$ was the most efficient one; it recorded mean number of dead individuals equal to 5.00 , in test 1 . The most efficient concentration used in test 2 was $1 \times 10^{10}$ conidia. $\mathrm{mL}^{-1}$, which recorded mean number of dead individuals equal to 4.60 , whereas the most efficient concentration used in test 3 was $1 \times 10^{10}$ conidia. $\mathrm{mL}^{-1}$, it recorded mean number of dead individuals equal to 3.80 . The treatment using the highest conidia concentration in the walking-on-powder experiment was actually the most efficient one (Figure 4).

Mean $\mathrm{LC}_{50}$ recorded in experiments based on the walking-on-powder method was $2.4 \times 10^{8}$ conidia. $^{-1}$; this value was close to the concentration of $5 \times 10^{8}$ conidia. $\mathrm{mL}^{-1}$.

Of the three application methods simultaneously tested with a single concentration of $1 \times 10^{8}$ conidia. $\mathrm{mL}^{-1}$, the method of walking on conidia powder deriving from $B$. bassiana has shown the best result mean mortality rate recorded for $H$. hampei was 4.0 (Figure 5).

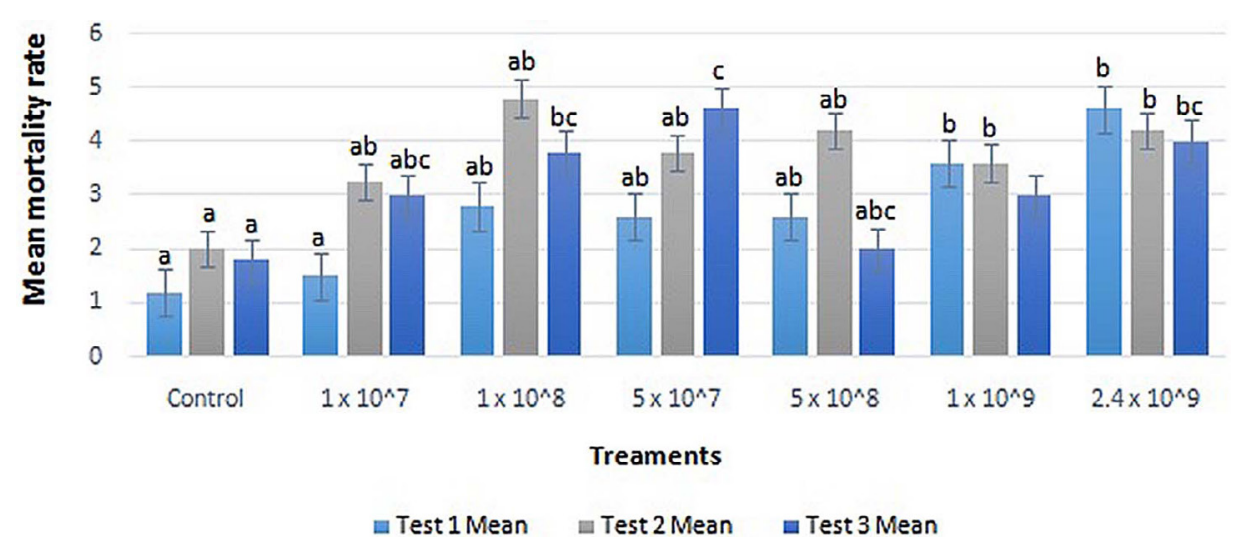

Figure 2: Mean mortality of Hypothenemus hampei female after immersion in Beauveria bassiana blastospore suspension (26 $\pm 1^{\circ} \mathrm{C}$; $\left.\mathrm{RH} \pm 47\right)$. Means followed by the same letter do not differ by the Tukey test $(\mathrm{P}<0.05)$. Original data being transformed by square root of $x+0.5$ in the analysis. 


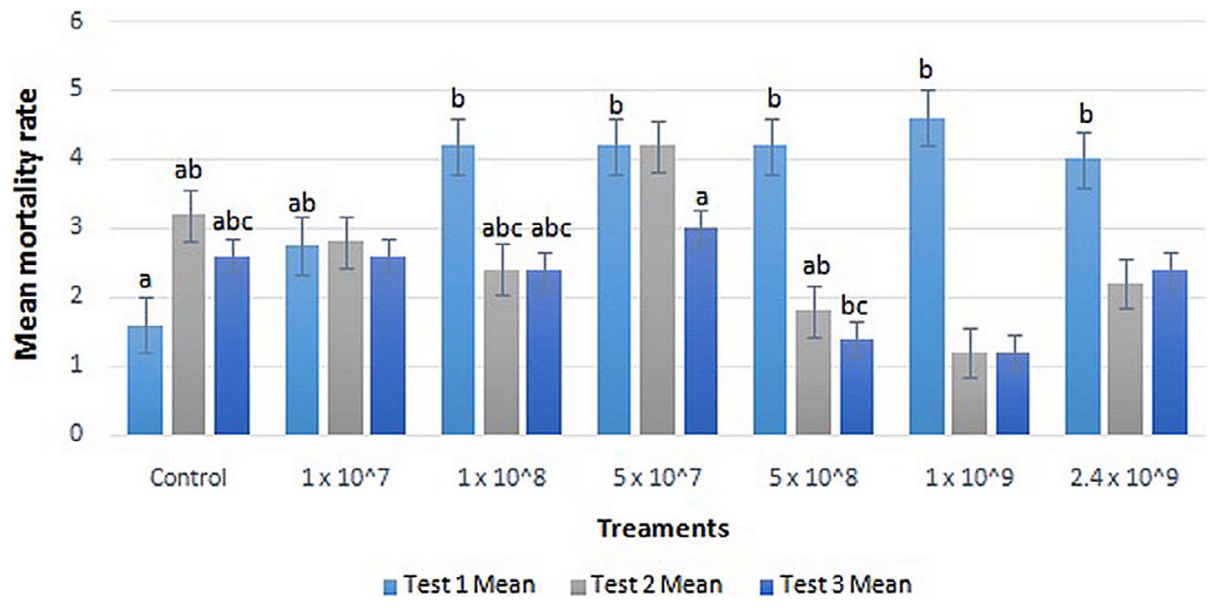

Figure 3: Mean mortality of Hypothenemus hampei females after spraying in Potter Tower, with conidia suspension of Beauveria bassiana $\left(26 \pm 1^{\circ} \mathrm{C} ; \mathrm{RH} \pm 47\right)$. Means followed by the same letter do not differ by the Tukey test $(\mathrm{P}<0.05)$. Original data being transformed by square root of $x+0.5$ in the analysis.

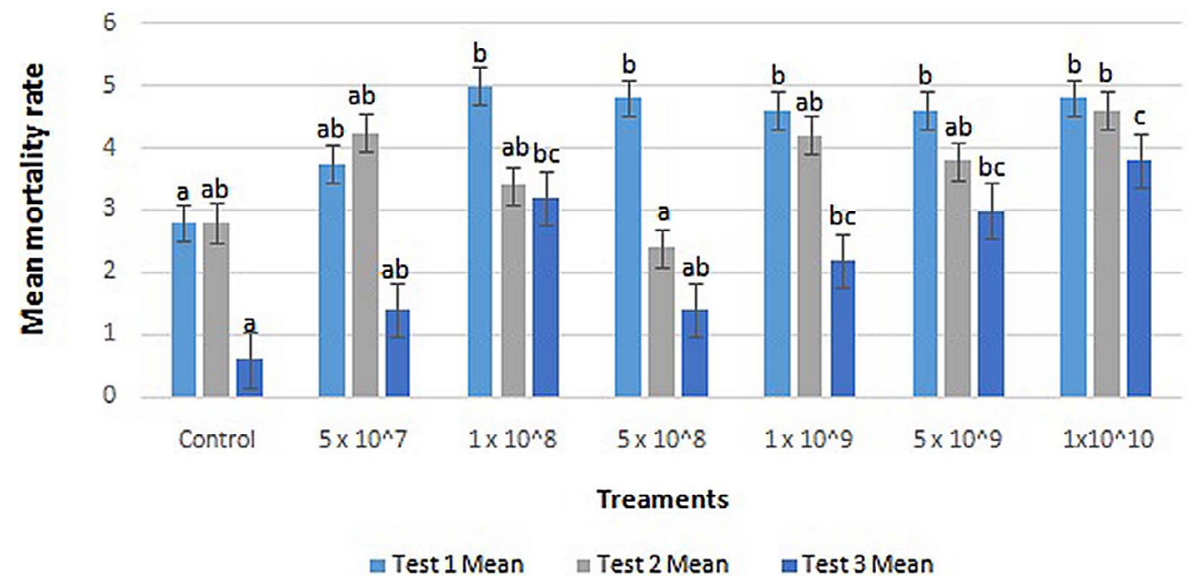

Figure 4: Mean mortality of Hypothenemus hampei females after walking conidia powder of Beauveria bassiana $\left(26 \pm 1^{\circ} \mathrm{C}\right.$; $\mathrm{RH}$ $\pm 47)$. Means followed by the same letter do not differ by the Tukey test $(P<0.05)$. Original data being transformed by square root of $x+0.5$ in the analysis.

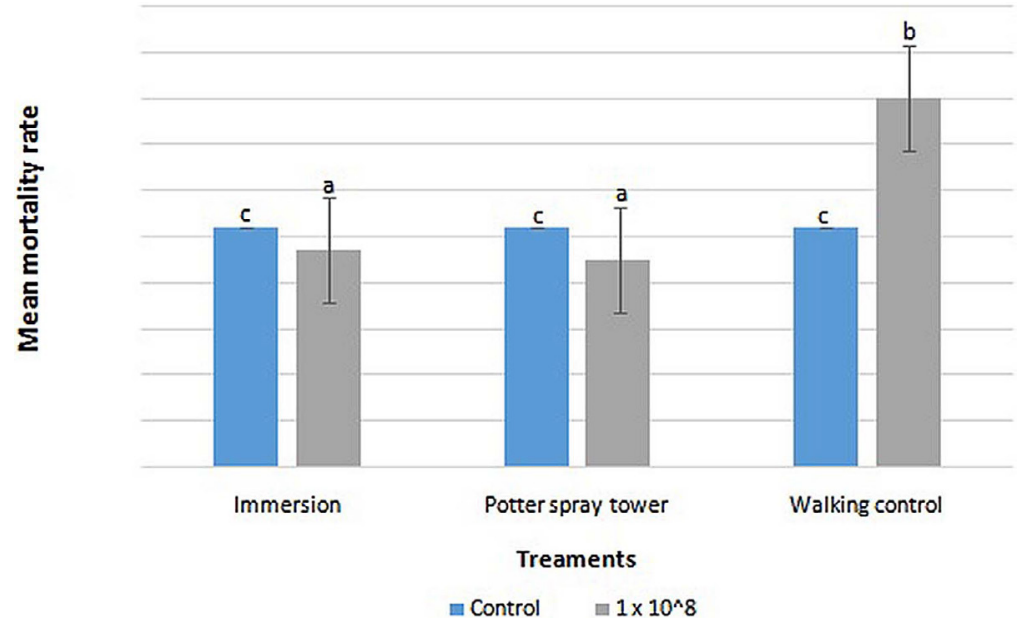

Figure 5: Mean mortality of Hypothenemus hampei females after comparison of the three methods of application of Beauveria bassiana $\left(26 \pm 1^{\circ} \mathrm{C} ; \mathrm{RH} \pm 47\right)$. Means followed by the same letter do not differ by the Tukey test $(P<0.05)$. Original data being transformed by square root of $x+0.5$ in the analysis. 
Mortality rate recorded for adult borers in experiments based on dry conidia powder application through the walking method was higher than that recorded for methods based on blastospore suspension application by immersion and on conidia spraying through Potter Spray Tower.

\section{DISCUSSION}

There are many articles based on comparing inoculation methods. However, none as used here. In immersion tests, the infectious structure of the blastospore was as efficient as their distance conidia. Blastospores are infectious to adult borers; they recorded mortality rate close to the one recorded for aerial conidia spraying, as well as similarity in sporulation observed under dead beetles' carcasses. Based on the statistical comparison between the 3 tests using the immersion method, the highest mortality rates were recorded for test 1 . Thus, the tests showed that experiments with blastospores, although with a lower mortality rate, control $H$. hampei.

Regarding tests 2 and 3 for the spraying method in Potter Tower, although in test 3 the low staverage mortality was registered for most treatments, it also registered the high staverage mortality in the concentration of $5 \times 10^{7}$ conidia.mL ${ }^{1}$. Wenzel, Giometti, and Almeida (2006), have investigated IBCB66 pathogenicity on Diatraea saccharalis caterpillars, based on the Potter Spray Tower method. Concentration of $5 \times 10^{7}, 1 \times 10^{8}$ and $5 \times 10^{8}$ conidia. $\mathrm{mL}^{-1}$ were statistically equal, since they recorded mortality rates ranging from $65 \%$ to $89 \%$. These results are similar to the ones observed for test 1. The low $H$. hampei mortality rate observed by Mota et al. (2017) in experiments based on the Potter Spray Tower method corroborates the current results. According to the author, these results can be explained by hydrophobic features of the conidium, as well as by the large number of chitinous structures observed in the dorsal part of borer's exoskeleton on, which would make it difficult for the fungus to adhere to the host's body. These arguments may justify the mortality rates observed in the current study since, unlike the experiments conducted by Mota et al. (2017) it did not use any adjuvant, despite the low mortality rates.

The control recorded higher mortality rates in tests 1 and 2 by walking-on-powder method, it exceeded the mortality rate recorded for concentrations of $5 \times 10^{7}$ conidia. $\mathrm{mL}^{-1}, 5 \times 10^{8}$ conidia. $\mathrm{mL}^{-1}$ and $1 \times 10^{9}$ conidia. $\mathrm{mL}^{-1}$ used in test 3 . Despite this result, all three experiments presented higher mortality levels than methods based on immersion in blastospores suspension and on Potter Spray Tower using, with fungal suspension comprising airborne conidia added to distilled water, without adjuvants. In research with $H$. hampei, Mota et al. (2017) shows high mortality due to exposure of the insect's ventral parts, which corroborates the results for the tests by the walking-onpowder method. Studies conducted by Batista-Filho, Abrahao and Cruz (1988), based on the walking-on-powder method and/or on body contact with the internal surface of traps impregnated with pure B. bassiana conidia recorded 100\% $H$. hampei mortality rate. This outcome can justify the high mortality rate recorded for $H$. hampei individuals subjected to the walking-on-airborne $B$. bassiana-conidia method adopted in experiments conducted in the present research.

Results in the current study have shown that, although B. bassiana blastospores are also infectious structures with potential to be used for biological control purposes, it is necessary conducting further studies about their application methods, as well as about the best formulation capable of keeping their infectious structure effective in field, Almeida (2020). In addition, the high mortality rate recorded for the pest beetle using the B. bassiana aerial conidia walking method, suggests the need for further studies aiming at the development of new technologies for the application of powdered conidia for use in the field.

\section{CONCLUSIONS}

Powdered conidia are more effective in controlling Hypothenemus hampei than blastospore suspensions.

The most efficient method of application was walking on conidia powder.

Further studies are still needed to identify a new application methodology for powder aerial conidia.

\section{ACKNOWLEDGMENT}

The authors are grateful to FUNDAG (Agricultural Support Foundation) for granting the Master's Degree scholarship.

\section{REFERENCES}

ALMEIDA, A. et al. Seleção de isolados de Beauveria bassiana para o controle de Cosmopolites sordidus (Germar, 1824) (Coleoptera: Curculionidae). Arquivos do Instituto Biológico, 76 (3):489-493, 2009.

ALMEIDA, J. E. M. Biofábricas para produção de micopesticidas no Brasil: Oportunidades de negócio e inovações. Brazilian Journal Animal Environmental Research, 3 (3):2544-2557, 2020.

ALVES, L. F. A.; NEVES, P. M. J. O.; FARIA, M. R. Recomendações para utilização de fungos entomopatogênicos no controle de pragas. $\mathrm{Cp}: 2$, Piracicaba:Rede Entomofungo, 2010. 52p. 2010.

ALVES, S. B. Fungos entomopatogênicos. In. ALVES, S.B. (ed). Controle microbiano de insetos. Piracicaba, SP: FEALQ, p. 289-381, 1998. 
ALVES, S. B. Perspectivas para a utilização de fungos entomopatogênico no controle de pragas no Brasil. Pesquisa agropecuária, 27:77- 86, 1992.

BATISTA FILHO, A.; ALVES, L.F.A.; MUNIZ, J.P. Determinação da eficiência de três concentrações de Beauveria bassiana (Bals.) Vuill. no controle de Hypothenemus hampei(Ferrari, 1867) (Coleoptera:Scolytidae). Revista de Agricultura, 67 (2):167-170, 1992.

BATISTA-FILHO, A.; ABRAHAO, J.; CRUZ, B. P. B. Contribuição ao estudo de Hypothenemus hampei. Arquivos do Instituto Biológico, 55:65, 1988.

BRASIL, Ministério da Agricultura, Pecuária e Abastecimento - MAPA,Café no Brasil. 2017. Disponívelem: $<\mathrm{http}: / /$ www.agricultura.gov.br/assuntos/ politica-agricola/cafe/cafeicultura-brasileira $>$. Data de acesso: 24 de junho de 2021.

BRASIL, Ministério da Agricultura, Pecuária e Abastecimento - MAPA, Sistema de Agrotóxico e Fitossanitário. 2020. Disponível em: $<$ http://indicadores. agricultura.gov.br/agrofit/index.htm>. Data de acesso: 24 de junho de 2021.

BRATODJOJO, R. R. R. et al. Effects of culture media on viability of Beauveria bassiana and it's pathogenicity against coffee bean borer (Hypothenemus hampei). Prooceding International Conferenceon Science and Enginnering, 3:49-53, 2020.

LAURENTINO, E; COSTA, J. N. M. Descrição e caracterização biológica da broca-do-café (Hypothenemus hampei, Ferrari 1867) no Estado de Rondônia. (Documentos90) Porto Velho: Embrapa Rondônia, 2004. 26p.

GERÓNIMO-TORRES, J. D. C. et al. Caracterización de aislamientos nativos de Beauveria bassiana y su patogenicidad hacia Hypothenemus hampei, em Tabasco, México. Revista Colombiana de Entomología, 42 (1):28-35,2016.

GUIMARÃES, C. O.; CORREIA, A. C. B.; FERREIRA, M. C. Pressão de aplicação com pulverizador de barra e eficiência de bioinseticidas fúngicos comerciais. Pesquisa Agropecuária Brasileira, 39 (12):11771182, 2004.

NEVES, P.M.O.J.; HIROSE, E. Seleção de isolados de Beauveria bassiana para o controle biológico da brocado-café, Hypothenemus hampei (Ferrari) (Coleoptera: Scolytidae). Neotropical Entomology, 34 (1) : 077 082, 2005.
INFANTE, F.; PÉREZ, J.; VEJA, F. E. Farming: Redirect research to control coffee pest. Nature, 489:502, 2012.

JARAMILLO, J. et al. Some like it hot: The influence and implications of climate change on coffee berry borer (Hypothenemus hampei) and coffee production inEastAfrica.PLoSONE,6 (9) : e24528, 2011.

JARAMILLO, J.; BORGEMEISTER, C.; BAKER, P.S. Coffee berry borer Hypothenemus hampei (Coleoptera: Curculionidae): Searching for sustainable control strategies. Bulletin of Entomological Research, 96 (3):223-233, 2006.

LEITE, L. G. et al. Produção de fungos entomopatogênicos. In: PINTO, A. S Ribeirão Preto: cap. 8 'Produção de fungos entomopatogênicos no laboratório de controle biológico do Instituto Biológico, Ribeirão Preto: A. S. Pinto, p. 53-63, 2003.

MASCARIN, G.M.; PAULI, G. Bioprodutos à base de fungos entomopatogênicos. In: VENZON, M.; PAULA JÚNIOR, T. J. De.; PALLINI, A.(Org.). Controle Alternativo de pragas e doenças na agricultura orgânica. 1 ed. Viçosa: U.R. EPAMIG ZM, v. 4, p. 169-195, 2010.

MOTA, L.H.C. et al. Autoinoculation trap for management of Hypothenemus hampei (Ferrari) with Beauveria bassiana (Bals.) in coffee crops. Biological Control, 111:32-39, 2017.

NEVES, P. M. O. J.; HIROSE, E. Seleção de isolados de Beauveria bassiana para o controle biológico da brocado-café, Hypothenemus hampei (Ferrari) (Coleoptera: Scolytidae).Neotropical Entomology, 34(1):077-082, 2005.

PARRA, J. R. P. et al. Controle Biológico: uma revisão inter e multidisciplinar. In: Parra, J.R.P.; Botelho, P.S.M.; Corrêa-Ferreira, B.S.; Bento, J.M.S.: Controle Biológico no Brasil: parasitóides e predadores, São Paulo: Manole, cap.8, p. 1 - 15, 2002.

PARRA, J. R. P.; REIS, P. R. Manejo integrado para as principais pragas da cafeicultura do Brasil. Fitossanidade. Visão Agrícola, (12):47 -50, 2013.

POSADA-FLÓREZ, F. J. Production of Beauveria bassiana fungal spores on rice to control the coffee berry borer, Hypothenemus hampei, in Colombia. Journal of Insect Science, 8 (1):41, 2008.

RODRIGUES, A. A. F.; ALMEIDA, G. R. R.; DUARTE, T. R. Tecnologias de aplicação de defensivos na cultura do cafeeiro. Revista Agroveterinária do Sul de Minas,1(1):1-14, 2019. 
SANTORO, P. H. et al. Interferência da metodologia nos resultados de bioensaios de seleção de fungos entomopatogênicos para o controle de insetos. Pesquisa Agropecuária Brasileira, 42 (4):483-489, 2007.

SOUZA, J. C. et al. Controle químico da broca-do-café com Cyantraniliprole. Coffee Science, 8 (4):404-410, 2013.
WENZEL, I. M.; GIOMETTI, F. H. C.; ALMEIDA, J. E. M. Patogenicidade do isolado IBCB66 de Beauveria bassiana à broca da cana-de-açúcar Diatraeasaccharalis em condições de laboratório. Arquivos do Instituto Biológico, 73 (2):259-261, 2006. 